\title{
Collective Action on Public Goods for Sustainable Development: Ethics in Action
}

http://doi.org/10.21272/bel.4(4).14-27.2020

Lichia Yiu, ORCID: https://orcid.org/0000-0002-7975-0810

Doctor of Education, Professor, Centre for Socio-Eco-Nomic Development (CSEND), Geneva, Switzerland

Raymond Saner, ORCID: https://orcid.org/0000-0001-6292-7141

$\mathrm{PhD}$, Professor, Basel University and Science Po, Paris, France; Diplomacy Dialogue, (CSEND), Geneva, Switzerland

Roland Bardy, ORCID: https://orcid.org/0000-0002-5061-0232

Doctor of Political Sciences, Executive Professor, Florida Gulf Coast University; Bardy Consult, Mannheim, Germany

\begin{abstract}
Maintaining and expanding public goods is synonymous to promoting sustainable development but discussions are needed to clarify how policies need to be coordinated to enable collective action on public goods. Collective action for Public Goods will only be successful if all who partake in such actions can gain complementary benefits that would be either more costly or impossible to achieve without the collective effort. Such complementary benefits are possible provided all stakeholders contributing to the public good of social peace and social cohesion cooperate with each other and preserve this and other public goods be they citizens, civil society organizations, all public authorities and all business firms. This concerted effort for a good cause can certainly be coined "ethics in action" - a notion which exhibits the moral foundation of the private and public choices inherent in sustainable development implementation of which interactions amongst stakeholders are no longer transactional, but rather aspiring toward greater good. Civil society organizations are key stakeholders producing, maintaining, and benefitting from Public Goods. They should strive for full inclusion, as there are many people who are either excluded or under-provided with respect to public goods. Public authorities, another key stakeholder group, need to cooperate with other stakeholders through collaborative frameworks and mechanisms for collective action that bind states and international organizations at a global scale. Another important stakeholder group, private and public enterprises need to operate within a level playing field globally, conduct business based on Responsible Business criteria and be welcomed to contribute to Public Goods creation in a sustainable and proactive manner without causing negative impacts due to their business activities. This paper presents and discusses how collective action can be achieved through concerted efforts by all members of society aiming to produce and maintain public goods essential for the sustained and equitable functioning of society. The UN 2030 Agenda for Sustainable Development serves as a shared roadmap in achieving shared future.
\end{abstract}

Keywords: Collective Action, Public Goods, Sustainable Development, Corporate Social Responsibility, UN Agenda 2030.

JEL Classification: H41, Q01.

This work is licensed under a Creative Commons Attribution 4.0 International License

Cite as: Yiu, L., Saner, R., Bardy, R. (2020). Collective Action on Public Goods for Sustainable Development: Ethics in Action. Business Ethics and Leadership, 4(4), 14-27. http://doi.org/10.21272/bel.4(4).14-27.2020.

(C) The Authors, 2020. This article is published with open access at Sumy State University.

\section{Introduction}

Framing the debate: The economic basis of collective societal success. The sustainable Development Goals of the 2030 Agenda consist of three interdependent dimensions namely sustainable social, economic and environment development. However, most implementations of the SDGs focus primarily on the environmental and economic dimensions. The social dimension gains less attention and is difficult to attain and operationalize (Nugraheni et al., 2019). This paper focuses on the social dimension of the SDGs and particularly on the Public 
Good of social peace and social cohesion and how they are produced, maintained and shared by society's stakeholders. Success or failure to cooperate by different stakeholders of society have been studied by economists and sociologists but also by philosophers like Jean Jacques Rousseau who proposed a Social Contract to ensure constructive engagement of society's main stakeholders. A collective action problem or social dilemma is a situation in which all individuals would be better off cooperating but fail to do so because of conflicting interests between individuals that discourage joint action. The collective action problem has been addressed in political philosophy for centuries, but was most clearly established in 1965 in Mancur Olson's The Logic of Collective Action $(1971,1965)$.

A good example of collective action is given by Ostrom (2012). A community that has made their living by fishing for centuries finds that have led to overfishing due to recently improved fishing techniques which resulted in a decrease of available fish stock. This is a problem no single fisherman can solve on his own. Even though their collective interest is to preserve the natural resource of fish, should they nevertheless maximize their fishing efforts, they will make every fisherman lose since the fish stock is decreased making fishing costly for fisherman. The way out of this trap is by collective rule-arrangements that realign individual incentives, e.g., by introducing quotas, or by regulating the time input appropriate for fishing, or by allocation rules that specify where individual fishers are allowed to harvest (Ostrom, 2012: 80). Transferring Ostrom's example of collective action by a (local) group of fishermen to the larger scale where cross-sector cooperation is required for effective partnerships in sustainable development, a fundamental question is whether all partners fully understand the needs and the opportunities in a situation that requires their on-going commitment and cooperation. Societal problems arise when too many group members choose to pursue individual profit and immediate satisfaction rather than behave in the group's best long-term interests. Social dilemmas can take many forms and are studied across disciplines such as psychology, economics, and political science. Examples of phenomena that can be explained using social dilemmas include resource depletion, low voter turnout, and overpopulation. The collective action problem can be applied to numerous public policy concerns that countries across the world currently face.

Narratives of different perspectives. Since the founding days of the United Nations, the public sector, private sector, and civil societies were recognized as three indispensable stakeholder groups of the development process. It goes without saying, they also constitute a dynamic arrangement within the development ecosystem where the production of public goods is essential for its vibrancy and sustainability. Cross-sector partnerships, horizontally and vertically, are the essence of this ecosystem, which the 2030 Agenda for Sustainable Development has defined as the Sustainable Development Goal 17. Representing three divergent worldviews, actors within each sector find it hard to collaboratively deal with actors of the other sectors. Instead, competition for the high ground forms part of the "wicked problems" when partnerships are key in solving the climate change challenges and deepening social injustice.

Partnering with the other - an important societal challenge. Civil society organisations (CSOs) have a critical role to play when forging cross-sector partnerships to accelerate the transition to a more sustainable and inclusive future. Good governance is an essential ingredient in this transition. Otherwise, well designed cross-sector partnerships between CSOs, governments and businesses will eventually fail as has been the case, e. g, with many Agenda 21 projects that were attempted after the 1992 UN Conference on Environment and Development held in Rio de Janeiro (the "Earth Summit"). A more significant part of these projects was to be implemented at the level of municipalities. While they produced an impressive amount of what may be called strategy production, i.e., stimulation of environmental citizenship, the inclusion of any sector that might want to contribute, challenging traditional assumptions and a call for more local democracy (see, e.g., Selman, 1998), specific results were scarce (Lafferty and Eckerberg, 2013). One reason for this disappointing result is, in many cases, there was a lack of resources. But another reason that reverberated, even in those well-funded projects, was the missing consensus on how to define the endeavours' outcomes. The project partners had conflicting ideas on explaining both the "public good" involved and the development outcome to be attained (Mittler, 2001).

CSOs must engage in co-design a sustainable future in the local context by giving voices to the residents. Consequently, CSOs need to play an active role in exercising the watchdog function to "oversee" multi-sector partnerships. But, for this, they must abstain from the often-observed aversion against fully including businesses in the process. The business's role must not be limited for funding but be included in the decision processes to create share values (Porter \& Kramer, 2011). Besides, the business community must homogenize their objectives that are sometimes conflicting. With the potent mandates CSOs receive from their constituencies, and with the many interlinkages between their various denominations, they have the power to assume a strategic position by influencing international public policymaking and accessing multiple entry 
points into the public policy debates. There is a new expectation on this that is nourished by the hope that financial and resource constraints of CSOs and ideological barriers can be surpassed in the world-wide endeavours to implement the 2030 Agenda for Sustainable development effort of building back "better" in a post-COVID-19 environment.

2030 Agenda for Sustainable Development - A Field of Co-Production. The 2030 Agenda for Sustainable Development case was selected to illustrate the potential and necessity of constructive interactions needed between the state, business, and civil society at different policy arenas, for this purpose. Not only this a fertile field for discussion, but it is also for its significance in determining our common future. Two critical international agreements must be achieved in the next decades if the world wants to have a sustainable future without ravaged by pandemics, extreme weather patterns, famine, displacement and armed conflicts. They are the 2030 Agenda for Sustainable Development (inter alias SDGs) and the Paris Agreement on Climate Change. Both international agreements have been signed by almost all world-building countries building on the UN Secretary General's proposal to work together for the "Future that We Want". They serve as the roadmap and the policy framework to achieve harmony between the people, planet, prosperity, peace, and partnership. There is no question that all these are linked with ethical issues concerning fundamental human rights and acceptable conduct. Most actors may understand this linkage, but there is less grip on how to translate that insight into fruitful cooperation. While the interdependence of people, societies, and the ecosystem has been highlighted in the 2030 Agenda, some countries and communities continue to operate in silos depreciating the possibilities of finding holistic and integrated long-term solutions for mankind's survival.

A fundamental "reset" needs to take place to rebalance and to address the challenges regarding natural disasters, conflicts, dislocations and financial instability and vulnerability. In the language of Jeffrey Sachs and his colleagues, they spoke of different transformations are required to achieve the SDGs and Paris Agreement with its modest targets. These transformations, suggested by Sachs et al. (2019), can be grouped into the following modules (Sachs et al., 2019):

Transformation 1: education, gender and inequality;

Transformation 2: health, well-being and demography;

Transformation 3: energy de-carbonization and sustainable industry;

Transformation 4: sustainable food, land, water and oceans;

Transformation 5: sustainable cities and communities;

Transformation 6: digital revolution for sustainable development.

These transformations require the ethical commitment to "leaving no one behind" and decoupling the existing business models from unsustainable consumption and production and transiting to a more circular economic activity type. Figure 1 presents the links between different SDGs and the holistic arrangement of their implementation. Each transformation listed in Figure 1 also points to priority investments and regulatory challenges, calling for government actions to work with business, scientific communities and civil society through collective efforts. Governments are entrusted with the central role of enabling these transformations. Through a broad-based national planning process and a robust policy coordination mechanism, transformations can be made possible within the government's current structures. 


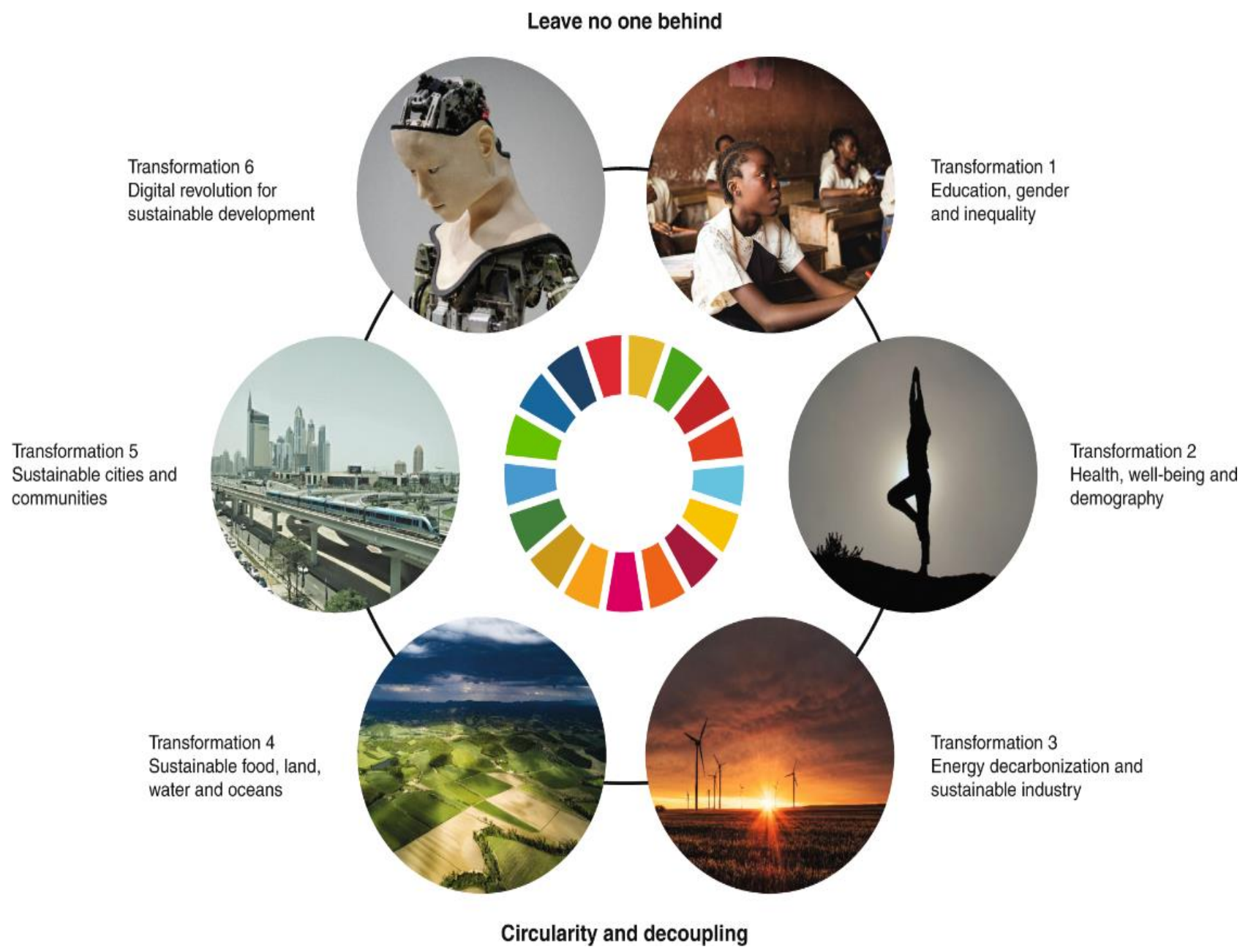

Figure 1. Transformations Are Required to Achieve the SDGs and Paris Agreement

Source: Sachs et al., 2019

Partnerships for collective actions are institutional arrangements that require oversights, data for resultsoriented monitoring, and good governance to succeed. To this extent, it is not sufficient that CSOs are given the rights to participate. They also need to be given meaningful roles, functions, and space in this triangular relationship where CSOs tend to be the weak component of the arrangement due to resource constraints.

\section{CSOs' Contribution to the Creation and Maintenance of Public Goods}

Good Governance. Public goods in this partnership context can consists of social infrastructure such as housing, hospitals, schools, water and sewage systems. It also includes timely data, monitoring capacity and effective feedback mechanisms to ensure CSOs abilities to ensure good governance. CSOs alone will not be able to attain these capabilities nor ensure good governance. Definition of governance or good governance varies. The one adopted here is from the Organization for Economic Cooperation and Development (OECD) and states the following: "Good governance is characterised by participation, transparency, accountability, rule of law, effectiveness, equity, etc." (OECD, 2006).

IMF in its Manual on Fiscal Transparency also defines good governance stating: "Good governance refers to the management of government in a manner that is essentially free of abuse and corruption, and with due regard for the rule of law." (IMF Glossary, 2007).

Principles of good governance usually consist of transparency, accountability, inclusiveness, equity, responsiveness, efficiency \& effectiveness, and participation (UNESCAP, 2009). Figure 2 presents a comparative view on good governance by selected international organisations. 


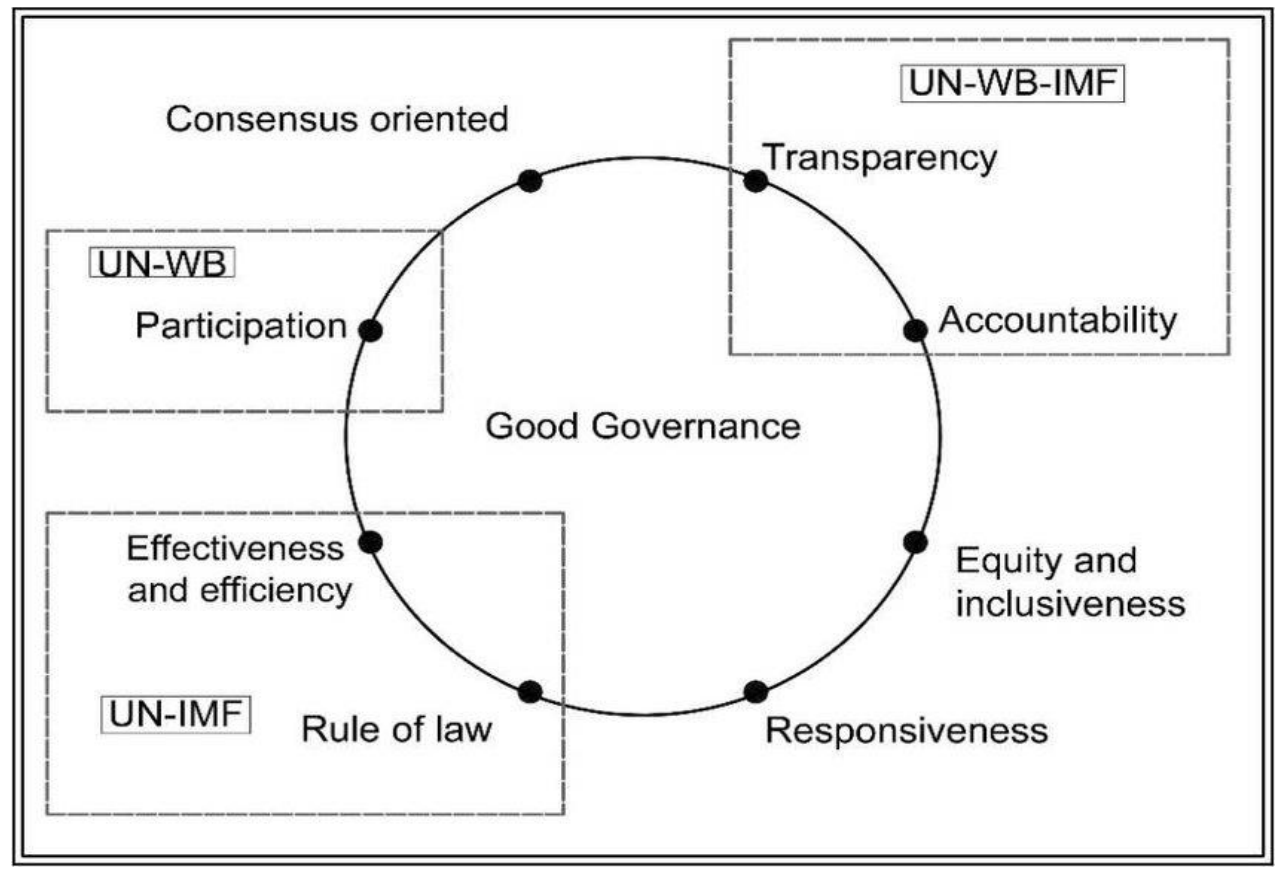

Figure 2. Eight Principles of Good Governance (UNESCAP, 2009) and Intersections with the WB and IMF Perception

Source: OMRAN, 2017

CSOs sandwiched between different power relations are there to safeguard social equity and the soundness of environmental policies by realizing good governance. As a third party, respecting the rules of the land, CSOs endeavour to ensure good governance and transparency that supports the functioning of a fair and just society as stipulated in SDG 16, "Promote peaceful and inclusive societies for sustainable development, provide access to justice for all and build effective, accountable and inclusive institutions at all levels" (https://sdgs.un.org/goals/goal16).

CSOs are the crucial linking pins to ensure that governance and political relationships function for all. According to Frahm and Martin (2009), the differences between government and governance rests on seven parameters, i.e., the role of government, authority and decision-making, system structure, focus, democratic processes, accountability, and policies (see Table 1). Therefore, governance is called the fourth dimension of the SDGs. In the coming decade, governance transformation needs to occur as the seventh transformation of SDG implementation, keeping many failed or fragile and authoritarian states. CSOs, as the guardians of public interest, are key partners in driving this seventh transformation, like their contributions to the other changes taking place around the world.

Table 1. Comparison between "Government" and "Governance"

\begin{tabular}{|l|l|l|}
\hline \multicolumn{1}{|c|}{ Dimension } & \multicolumn{1}{c|}{ Government } & \multicolumn{1}{c|}{ Governance } \\
\hline The Role of Government & Major Actor & One of Many Actors \\
\hline Authority \& Decision Making & Centalized Command \& Control & Decentralized Negotiation \& Persuasion \\
\hline System Structure & Closed \& Vertical & Open \& Horizontal \\
\hline Focus & Program & Tool \\
\hline Democratic Process & Representative & Participatory \\
\hline Accountability & Process Outputs Quality Outcomes & Community Level Outcomes \\
\hline Policies & Centralized/ Uniform & Decentralized/Place Sensitive \\
\hline
\end{tabular}

Source: Frahm and Martin, 2009

The relationship between CSOs and the 7th transformation is complex entailing different opportunities and challenges for CSOs. The democratization of public policymaking, which impacts the national investment policies and availability of public goods, such as ICT and data, may lower or raise the thresholds for CSOs to enhance and assure good governance. Nevertheless, it is also recognized that to be so engaged in governance issues entails high personal risks for CSOs representatives, particularly in countries characterized by authoritarian leadership and violation of basic human rights.

Engagement with the International Public Policy Negotiations. Saner and Michalun (2009) proposed a multistakeholder model concerning global governance and public policy making that highlighted the interactions 
and participation of varied actors in setting global agenda and standards consisting of governments, multinational companies, I-NGOs and IOs (see Figure 3).

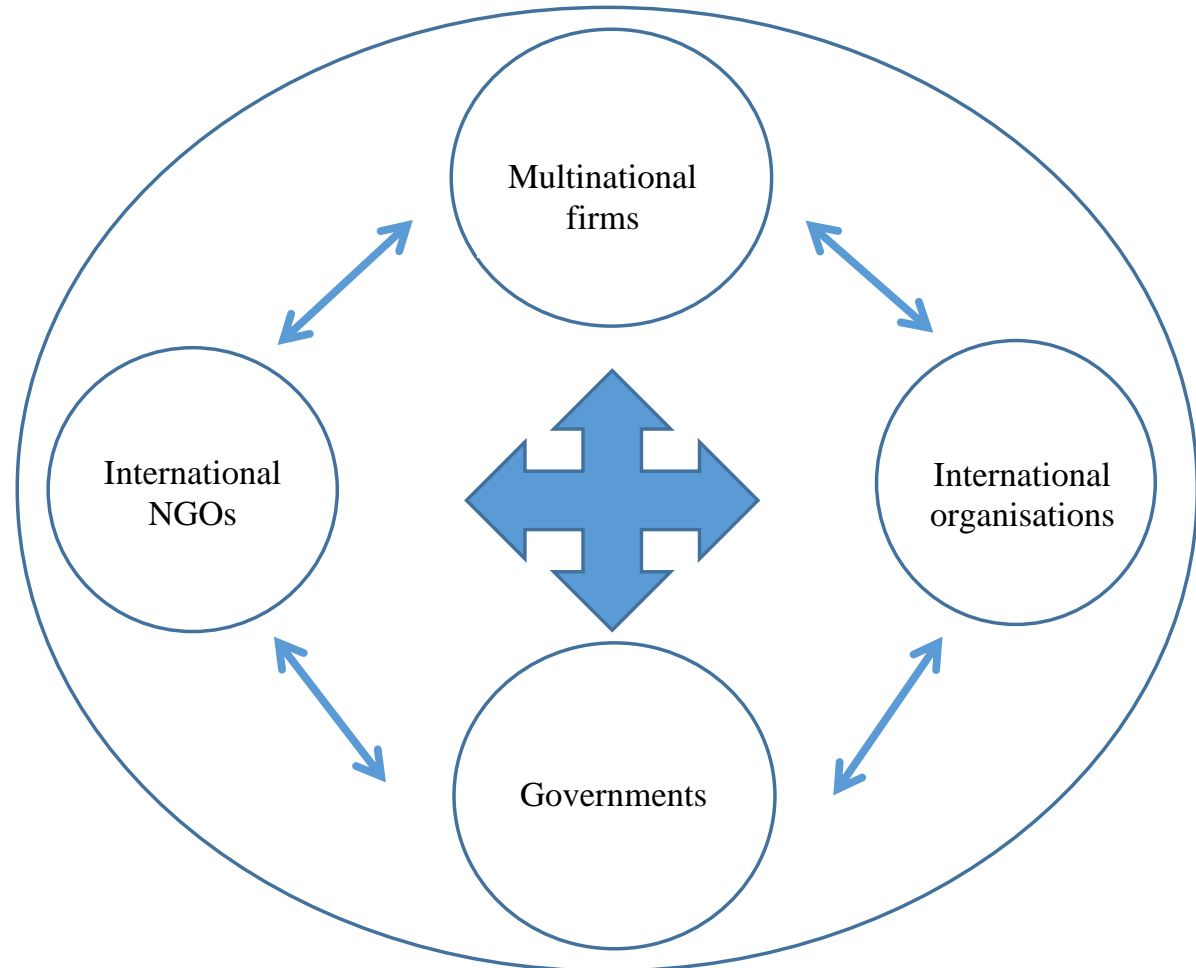

Figure 3. Stakeholder Interaction in the Public Arena

Source: Saner and Michalun, 2009, p. 22

Relationships between the UN and NGOs or global civil society have changed a lot since the 1990s. This change was triggered by both a UN resolution recognizing the importance of CSO's as part of the global community and was also triggered by an angry outpouring of citizens across many countries expressing dissatisfaction with globalization, social hardships and increasing discrepancies between the wealthy and poor segments of society in many countries (Saner and Yiu, 2014). During the SDGs negotiations from 2013-2015, a cross-sector dialogue was set up within the context of the SDG negotiation and the UN Open Working Group was created to foster shared vision (Yiu and Saner, 2014). Simultaneously a High-Level Political Forum was also established for coordination amongst member states. The UN OWG also consisted of members of scientific communities and members of the CSOs. Non-state actors are grouped into Major Groups and Other Stakeholders (MGoS) to avoid chaos and ensure effective and efficient implementation of the 2030 Agenda. While all MGoS are present in the UN and its affiliated organizations' SDG-related processes, coordination amongst these non-state actors is voluntary and relatively weak across the whole spectrum of the MGoS. Depending on the resources available and on organizational capabilities, different CSO groupings have varied possibilities in actively participating and engaging in on-going monitoring. Private sector companies participate in the UN SDG process through the Major Group (MG) mechanism of "Business and Industry".

The International Organisation of Employers is the organizing partners of this MG. An additional channel of the private sector engagement at the UN is the UN Compact affiliated with the UN Foundation. Non-state and non-business MGs represent the largest number of members, yet with diverse capacities, experiences and wishes. It is also obvious, capacity for resource mobilization, these MGs fall far behind the governments and businesses and cannot carry out needed data collection, analysis, articulation, and outreach on time, except a handful of significant I-NGOs, such as Oxfam, ActionAid, Worldwide Wildlife Fund, just to name a few. Through the MGs coordination mechanism, CSOs can interact and negotiate with the business and industry group within the UN ECOSOC context regarding the final details of the national implementation of SDGs. However, this coordination mechanism is neither robust nor funded, except one UN officials oversee this task to fulfill this vision. Instead, regional Commissions for Economics are often better forums for the CSOs to engage locally. Still, funding presents similar barriers for active participation by the CSOs at the local level as well. Partnership, or coalition building, would be the necessary strategy to influence or to steer the direction or common position of the MGs. However, there are many obstacles to this strategy. Again, resource availability plays a crucial determining factor here. Voices of the CSOs representing the marginal or invisible groups are often left out of the policy consultation. 
Influencing and Partnering at the strategic entry points. Experiences have shown that to be effective, advocacy needs to be timed with the policy cycle. NGOs or CSOs need to be strategic in their campaigning and intervention and enter the right policy space with different tactics. Saner and Michalun (2009) visualized the international policy-making cycle and pinpointed the various entry points for CSOs to intervene with specific contributions to make and roles to play (see Figure 4). The global policy-making cycle consists of six phases: (re-)framing, agenda-setting, policy negotiations, standard-setting, watchdog, and whistleblowing. Depending on the resources and competence available, CSOs can influence the policy outcome in a meaningful manner. Partnerships with other actors, such as international NGOs, businesses, even governments, could allow the CSOs to contribute alternative or additional perspectives resulting in more targeted policy formulation.

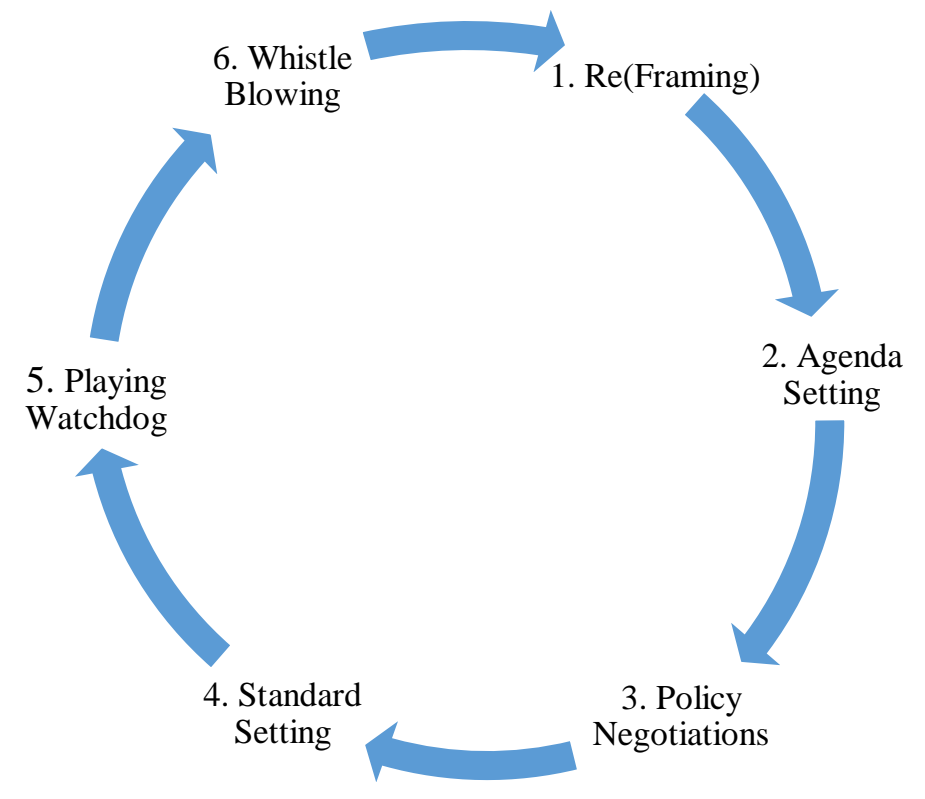

Figure 4. The International Policy Making Cycle and Space for Entry

Source: Saner and Michalun, 2009, p. 28

While the gain of such a strategic alliance is evident, the risk is that voices of CSOs could be drawn out by other actors with greater capacity and means. Therefore, the partnership is necessary for the CSOs to engage in the policy debate and in the monitoring of governance practices. Yet, the risk remains high in losing independence and getting co-opted by the other actors.

\section{Building a common framework for collective action to implement the SDGs}

There is a pressing challenge for developing the capacity of all public institutions (or administration) to lead collaboratively and effectively work across sectors countries, similar to what has been stated above for the nexus between CSOs and the business sector. Short of this leadership capacity, the interface management necessary to effectively address the system interdependencies will falter. The other challenge concerns social innovation. Developing and deploying effective new solutions to address demanding social and environmental concerns that are often systemic will require common resources to support social progress. There is an urgent need to create new forms of social cohesion and cooperation to catalyze this innovative framing at all levels of nexus and dependencies (Bardy, Rubens and Massaro, 2015). The next section of the paper describes and discusses how governments and businesses can collaborate by creating collective action that incites crossstakeholder collaboration, be this in the form of government and business or business with civil society partnerships in the context of the 2030 Agenda.

Innovative forms of collaboration across stakeholder-divides to build common resources. Although UN member states led the process of arriving at the 2030 development agenda, participation by non-state actors such as civil society stakeholders and business associations was crucial to conclude agreements. A sense of shared ownership and converging visions permeated the whole negotiation process, including setting the targets and implementing the agenda cutting across all sectors. Like the SDG negotiations, the SDGs' implementation also requires a multi-party collaborative process based on diverse actors' coordinated and complementary actions. These actors and stakeholder groups, i.e., governments, business, and civil society, 
are expected to produce the public and private goods, services, and common resources listed as goals and targets in the 2020 Agenda.

Successful implementation of the 17 SDGs (see Figure 5) is best captured by the call of "leaving no one behind," which exalt universal coverage and equitable treatment of all. A significant part of reaching the 17 goals of the 2030 Agenda requires investments in crucial physical and social infrastructure. Physical infrastructure means energy, transportation, water, telecommunications, and social infrastructure, including health, education, sanitation, and sewage systems. The financial sources needed for investment in infrastructure can be Foreign Direct Investment or Domestic Investment and could be based on government and public procurement or Public-Private partnerships (PPPs), and PPPs could be structured in the form of concessional and/or equity-type. Close engagements of the public, private and civil society will be necessary for these infrastructure investments to benefit all, even when cost efficiency might not be achieved for remote, difficult and sparsely populated terrains. Alternative delivery modalities need to be devised in ensuring the fair share of benefits from such investment. There is a need for a framework agreement with shared purpose and objectives, resulting in a transparent monitoring infrastructure to support collective actions.
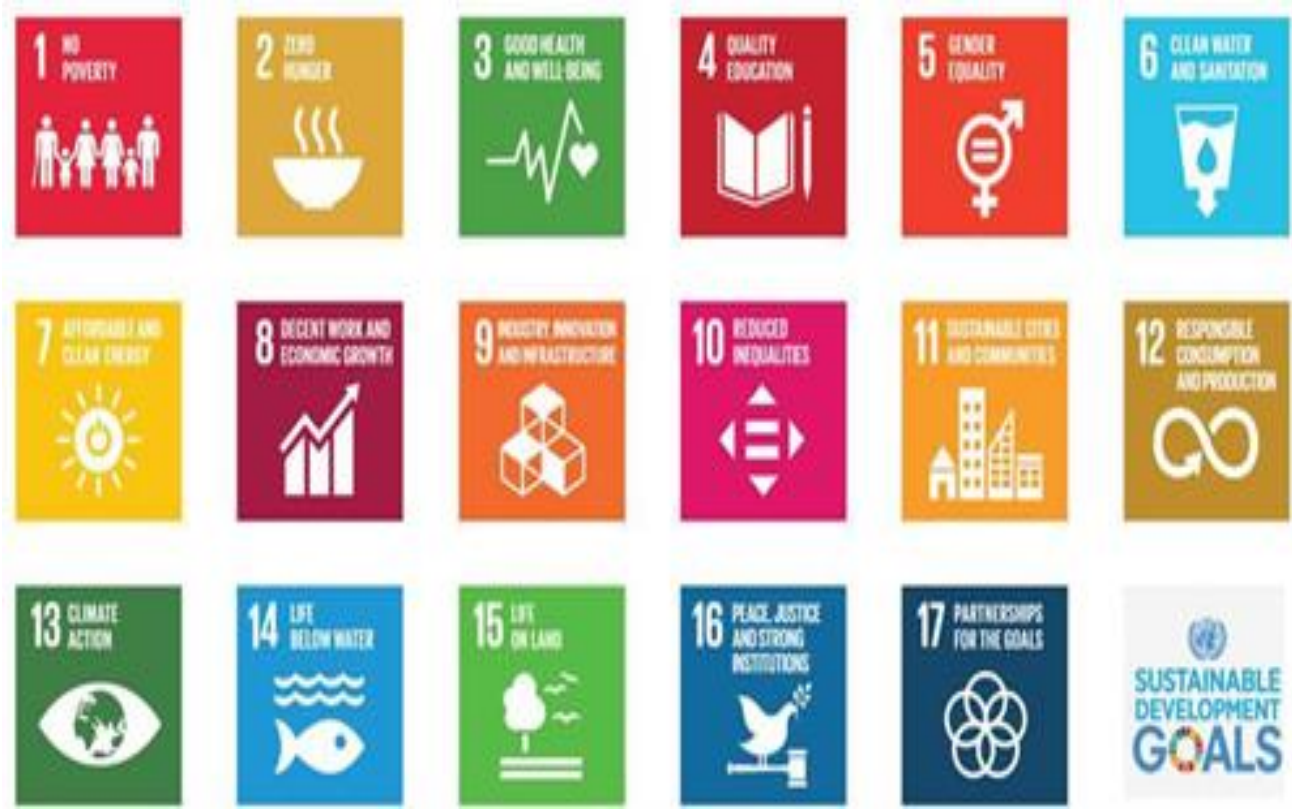

Figure 5. The 17 Sustainable Development Goals

Source: United Nations website, https: //www.un.org/sustainabledevelopment/sustainable-development-goals/

Unique Business Contributions to collective SDG implementation. Business can contribute to collective action by aligning its production and distribution process with the SDGs. Impact of such alignment could be felt in the bottom-line of the business endeavour through innovation and reputational gains, but also through bridging the existing financing gaps for SDG implementation. The example given in Figure 6 shows for instance how a company specialized in the manufacturing business can analyze different aspects of its domestic supply and value chains and production processes and identify both positive and negative impact on the SDG Goals and Targets. The horizontal bar in Figure 6 depicts the linear process of the value chain, while at the same time lists the relevant SDGs along this business process that could be impacted. These impacts could be positive or negative (depicted as $+/-$ ). and grouped at different steps of the value chain. Positive contributions are listed on the upper part of the bar, negative impact on the SDGs. The hypothetical manufacturing company depicted in Figure 6 has identified four positive impacts and seven negative impacts on the achievement of SDGs from the perspective of business activities. How to leverage the potential positive impact and minimize the negative impact requires broad based consultations inside and outside of the company to come up with preferably win-win or synergistic solutions. Such co-creation process needs to be supported by the business as part of its ethical conduct and value DNA. 


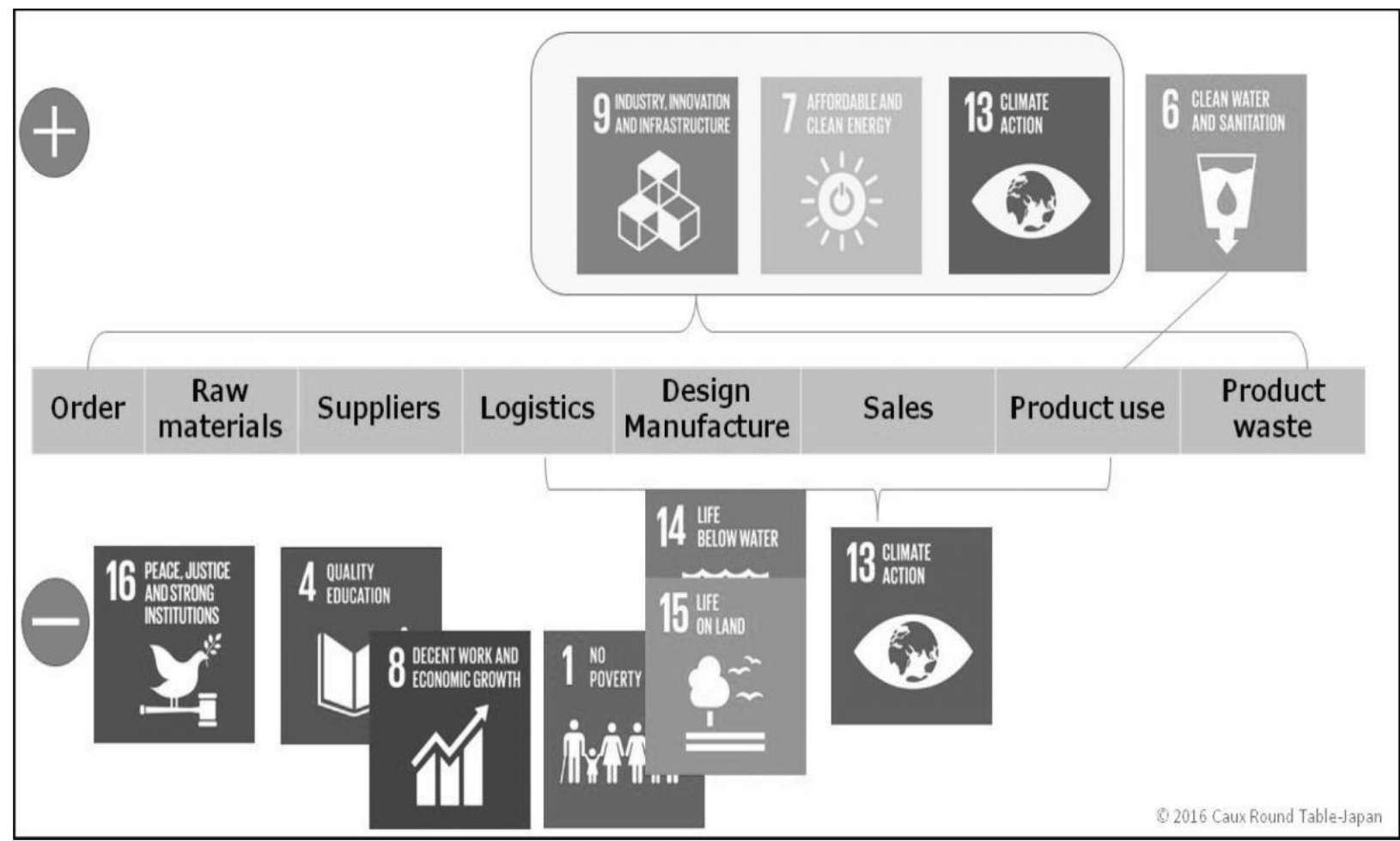

Figure 6. Impact Assessment of the 17 SDG Goals on the Core Business Processes within the Company

Source: Human Rights due Diligence Workshop, Manufacturing Infrastructure, 2016, Caux Round Table, Tokyo

Integrative Contribution of NGOs and Civil Society to the monitoring of collective SDG implementation for Generative Transformation. An important role of civil society is to check whether the SDGs are implemented as promised by the governments. Such checking is possible during the time of evaluation of country implementation but should also be conducted continuously during the 15-year implementation period through careful, professional and constructive monitoring of a country's performance. At the global level, this role is being filled by the UN Sustainable Development Solutions Network (SDSN), a multi-stakeholder group and tasked with providing annual review and reporting on the progress made in implementation SDGs globally. The Global Partnership for SDGs is also there to gather missing data and close the data gap. While global reporting on the progress made in SDGs implementation is necessary, an 'outer space' (expert-driven macrodata) perspective of global monitoring offers little to the local administrations and concerned actors. At best, global monitoring adds pressure for engagement through the impact of "shame and blame". SDGs are essentially arbitraged and prioritized in the country.

As is often said, "all development is local." Monitoring and corresponding data generation and data collection need to reflect this operational reality and address the "user" concerns where services are provided. The monitoring effort and data transparency need to reflect the commitment of not leaving the marginalized, invisible, and voiceless population behind at the sub-national and local levels. With the evolution of ICTs, "New" SDG monitoring processes can combine computer science, information systems, development studies and system thinking. A new SDG monitoring process would move from assessing if "needs" - often defined by external experts - have been 'put' to a process where the real internal 'needs' of a community takes precedence. A new SDG monitoring process would capture the situation at different times and space and record how implementation has been done, by whom and why within the community. Here the collaborative effort of the CSOs and Business communities could be beneficial in creating feedback loops for adjustment and amplification.

\section{Social effectiveness in collective action: Examples and requisites}

Effectively monitoring is the most decisive prerequisite to guarantee the fruitful outcome of a project when it has been started. But it will only be put into motion if all project partners are convinced that their specific interests are truly represented in the collective action. It brings us to the third perspective, which is that of the business sector. There is a long history of business involvement in community affairs, one field where social sustainability can be procured through collective action. And this is where society can check whether businesses act responsibly and whether the term "corporate citizenship", coined by the U.S. Management Professor Archie B. Carroll (Carroll, 1991), applies to a specific behaviour of a specific firm. Let us briefly 
look back to the origins, which can be found, without question, in corporate philanthropy. In Britain, for instance. There were entrepreneurs such as Cadbury and Rowntree and the Lever Brothers who were "corporate citizens" in the 19th-century (Bush et al., 2008) and engaged in what today we call "social partnerships" (Waddock, 1988). Their engagement was about providing accommodation and housing for employees, health services and education. It has been aptly called "Business ethics in action" by Crane et al. (2019) with which they refer to a term that connects to basic principles of moral and political philosophy that form the fundament of collective action (Calleja and Melé, 2016; Munro, 2008).

Collective action can also be undertaken through corporate social responsibility. BASF, the chemical conglomerate, had started to provide affordable housing, health insurance plans, on-site medical facilities and recreational facilities for its employees and their families as early as in the 1870s, and it also was one of the first to provide and implement occupational health and safety practices in the workplace. About 100 years later, now at a global level, BASF was one of 44 companies to sign on to the Global Compact upon its inception in July 2000. Like many other business firms, it benefits from the strategic use of moral commitments in its stakeholder relations, which is one prerequisite for successfully managing the trade-off situations between economic and ecological of sustainable development (Beckmann, Hielscher, Pies, 2014). To demonstrate its commitment to the Global Compact BASF launched or became a contributing partner in projects in over 25 developing countries. One example that affects a range of SDG goals is the Micronutrient Malnutrition Initiative started in Kenya in 2007. It is also a good example in showcase effective partnerships between business, the public and other non-state actors. Example: BASF's Micronutrient Malnutrition Initiative (MMI, see Bianchi 2007).

Micronutrient deficiency is a particular form of malnutrition where an individual does not receive the essential recommended intake of vitamins and minerals, often referred to as "hidden hunger." More than 2 billion people worldwide are affected by micronutrient deficiencies and an estimated one million people die annually from Vitamin A deficiency alone. The relevance of adequate nutrient intake is recognized under the International Covenant on Economic, Social and Cultural Rights (ICESCR), a part of the International Bill of Human Rights. In developing and implementing the project, BASF entered some partnerships. These include:

The Global Alliance for Improved Nutrition (GAIN), a Swiss-based NGO that was developed at the UN 2002 Special Session of the General Assembly on Children;

$>$ Maplecroft, a specialist research and advisory company that focuses on the non-financial performance of multinationals. Its venture with BASF resulted in a new, interactive global map of hunger;

$>$ GTZ, the German Agency for Technical Cooperation that provides technical capacity building to local food industries and facilitates multi-stakeholder workshops at the country level.

Here are the challenges confronting this MMI initiative:

\section{Challenges}

BASF has a limited presence in many developing countries, especially in Africa, where the project is performed in several places.

BASF produces vitamins but not minerals or iodine. Its expertise and product solutions only deal with one-half of the malnutrition issue.

The identification of suitable food vehicles for fortification requires the sourcing of a widely consumed and affordable staple food. There are cultural differences among the regions concerned.

Traditionally, aid for malnutrition focuses on ad hoc solutions, such as distribution of supplemental vitamin capsules. E.g., NGOs often provide non-fortified food aid, which can delay the process.

Donors increasingly demand solutions that, while market-based, are connected to their programs.

Internally, conflicts may arise between the distribution of resources and BASF's goal of long-term economic sustainability.

\section{Solutions}

Relying on partners and outside sources for capacity building and training that enables farmers to produce the suitable "fortified" food products.

This challenge is tackled, again, through collaboration with various partners, especially from GAIN and its network.

Partnering with local authorities / ministries of agriculture. But public partners may hesitate to join the project because it falls outside the usual scope of the partnerships that they engage in.

Working with NGOs through advocacy to make them aware that of the need to address both the macronutrient and micronutrient challenges, and, hence, alter their practices. $•$

Aiming for the long-term self-sufficiency of all programs and initiatives.

Management must decide between private tenders and tenders to the Initiative. 
Participation in the MMI initiative had to give proof of the business case before receiving the greenlight from top management of the company. The project management presented ten arguments:

1. contributing to the corporate citizenship profile

2.increasing employee motivation, attracting prospective employees

3. gaining positive recognition among stakeholders in governmental relations

4. developing markets in developing countries in times when growth in mature economies is low

5. addressing needs of under-served populations at the "base of the economic pyramid, including the potential to grow these markets
6. multi-layered benefits from partnering with the UN and nonprofit organizations

7 opportunities for tenders and business opportunities unrelated to the project

8 economies of scale: the larger the project, the larger the target group reached, the higher the likelihood of the initiative's long-term sustainability and success

9 at the macro level, relatively low costs with high social returns

10 demonstrating BASF's commitment to contribute to the UN Global Compact

\section{Other Examples: Rio Tinto and Earthwatch, Royal Bank of Scotland and Prince Charles Charity Trust.}

There are thousands of similar partnerships inside of the SDG scope or around it. At Rotterdam School of Management, Erasmus University (RSM), Rob van Tulder has founded the Partnerships Resource Centre (https://www.rsm.nl/research/centres/prc/) with the mission of conducting research and providing advises in this field. The Centre has listed dozens of notable partnerships, for example, of oil magnate Chevron and food giant Unilever (Belal, 2017; van Tulder and van der Zwart, 2005), which have been in existence for quite some time and which work for the social good in many countries. While many such partnerships exist, many failed to deliver the expected results. What are the learnings from the research conducted at the PRC of Erasmus University? What factors have contributed to the success of specific cased highlighted by the PRC? Two prominent cases in this regard will be unpacked. One is the partnership between the mining firm Rio Tinto and the large international charity Earthwatch; the other is between the Royal Bank of Scotland and Prince Charles' Charity Trust. Both cases examined the relationship arrangement between a private company and a philanthropic organization.

Success Factor 1 - Due diligence to determine partnership suitability. Rio Tinto and Earthwatch established a joint undertaking related to ecological concerns in various mining locations of RioTinto, while the partnership between the Prince's Trust and Royal Bank of Scotland was about helping young people aged 11 to 30 get into jobs, education and training. What sets these two partnerships apart from any other undertaking is that they did extensive due diligence before entering the venture. Measures consisted of building the necessary internal audit structures, i.e., defining "milestones", progress reports and corrective action, the thorough conceptualization of the various instruments to be applied, accountability reporting to the relevant stakeholders and, above all, partner suitability. It is shown in the following table (Table 2; Seitanidi and Crane, 2009: 19). Partner suitability, as shown in the table, is most important. Many ventures have failed in the early stages because of misunderstandings, insufficient knowledge and lack of risk management between partners (Doskočil and Lacko, 2018). Also, many projects require a change in people's mindsets. Often this underlying meta-perspective that supports a successful transformation is neglected nor understood.

Table 2. Factors Used for Qualifying Partner Suitability by Two Partnerships

\begin{tabular}{|c|c|}
\hline $\begin{array}{l}\text { Partnership A: } \\
\text { Earthwatch-Rio Tinto }\end{array}$ & $\begin{array}{l}\text { Partnership B: } \\
\text { Prince's Trust-Royal Bank of Scotland }\end{array}$ \\
\hline $\begin{array}{l}\text { Previous experience working across different economic sectors. } \\
\text { Covering similar geographical areas (with headquarters both } \\
\text { organizations in Melbourne-Australia and in London-UK). } \\
\text { Cost effective relationship (money/time investment vs expected } \\
\text { outcomes). } \\
\text { 'Safe' profiling platform* (within the business and the non- } \\
\text { profit sectors). } \\
\text { Mutual interests: biodiversity. } \\
\text { Personal chemistry among the core people across the two } \\
\text { organizations. }\end{array}$ & $\begin{array}{l}\text { Previous experience working across different economic } \\
\text { sectors. } \\
\text { Covering similar geographical areas (Royal Bank of } \\
\text { Scotland has branches all over the UK as well as Prince's } \\
\text { Trust has regional offices). } \\
\text { Cost effective relationship (money/time investment vs } \\
\text { expected outcomes). } \\
\text { 'Safe' profiling platform* (within the business and the non- } \\
\text { profit sectors). } \\
\text { Mutual interests: social exclusion; business start-ups. } \\
\text { Personal chemistry among the core people across the two } \\
\text { organizations. } \\
\text { Both organizations had Royal affiliations. }\end{array}$ \\
\hline
\end{tabular}

Source: Seitanidi and Crane 2009, p. 27

Of the seven success factors identified individually for partner suitability, six are shared between both partnerships except one factor. In the case of Earthwatch-Rio Tinto, it is the time scales of operation; in the 
case of Prince's Trust-Royal Bank of Scotland, royal affiliation. But there is a cultural similarity of both partner organizations. They share safe profiling, which proactively prevents any misuse of partner information over the Internet - an essential prerequisite for undertakings that involve a multitude of different users.

Other Parameters for Successful Partnerships. Prior experience in implementing Agenda 21 can also offer hints of best practices. By the end of the 20th century, many shortcomings of partnership arrangements were overcome, leading to a great deal of failed Local Agenda 21 projects or mixed outcomes. Many of them were implemented at the municipality level by stimulating environmental citizenship, including any sector that might want to contribute, challenging traditional assumptions and issuing a call for more local democracy (Selman, 1998). Yet, specifics were scarce (Lafferty and Eckerberg, 2013). The main reason for failure was not insufficient funding; it was a mindset. There was no consensus how to define outcomes of the endeavours, and disagreement on how to define the "public good" that was involved and the development to be attained (Mittler, 2001).

Today, more governance instruments are available and the public mostly accepts these instruments: (1) outcome-oriented project controlling, (2) public tenders for procurement; (3) fiscal measures, where necessary and (4) an investment in the social system - e.g., raising the competency of the people who participate in the process and reaching out to partners beyond the community affected by a project. Yet, a shared mindset could be said a shared resource that would make or break a cross-sector/border partnership remains central to collaborative actions but remain "invisible" and "dormant". It is the same in achieving the SDGs Agenda, which builds on a new awareness and various societal actors' perceptions. A significant shift regarding the SDG mindset is the perception that is not only state institutions need to promote social development, but that all relevant actors in society can and should contribute to solving development problems. Sustainable development is a co-creation process of value addition. The comparison between the two partnership arrangements discussed in the preceding text offers significant insight into the effective partnering between private and non-profit actors.

\section{Reframing the Antagonistic Narratives and New Normal}

Within the limited time available to avoid a significant sustainability catastrophe, the antagonistic narratives need to be shifted to a more collaborative narrative. Civil society organizations and elected officials or parliament members need to opt for constructive engagement with the corporate world regarding social and environmental issues and reconsider simplistic accusations that business involvement is purely for selfinterests and reputational gains. On the other hand, businesses need to stop seeing the state regulatory mitigation as meddling and invisible hand to restrict business development. Both need to change their perception of the civil societies as troublemakers that stir up disquiet amongst the stakeholders. To address the root causes of societal challenges within the remaining time of ten more years require radical change and collaborative processes that call for institutional learning and reaffirmation of social order and its ethical foundations. In this context, the corporate sector must clearly expel irresponsible business conduct cases through self-regulation and partnership with civil society organizations in third-party monitoring and due diligence. Then, in the words of former UN General Secretary Ban-Ki-Moon, "business can be a global force for the public good with advocacy and example driving action to achieve a life of dignity for all people" (UN News, 9 January 2015).

\section{Conclusion}

The SDGs aim to enable people's understanding of the world in fundamentally new ways and behave accordingly. They call for people to work together to bridge the complex differences that define human lives. Implementing the SDGs and creating the public goods needed for sustainable development means that all parties - government, business and civil society- are expected to play a collective role in the communities where they reside by bringing about economic growth, social development, and conservation of the environment. This collective role must include a common understanding of the new (social) ethical base to be accomplished through the SDGs.

Major businesses have found out for a long time that it is not acceptable to adhere to the reactive and minimalist stance of "Do-No-Harm" when managing their business impact and that, instead, they should actively pursue a proactive path that consists of adding values to the social fairness and environmental stewardship. When businesses invest in host countries, hire local employees, purchase goods and services from local vendors, train local staff, and set knowledge transfer foundations. It is not a philanthropic effort - it enables businesses to remain competitive globally in the sector they are in. At the same time, this fulfills multiple stakeholder expectations at home and abroad, including non-business partners like NGOs and CSOs. A new understanding 
of how to partake in collective action also seems to ascend in the hard-core CSOs. One example is the extremist "Extinction Rebellion," which is now proclaiming the principles of "actively mitigating for power" and "avoidance of blaming and shaming" (https://rebellion.earth).

The authors of this paper are convinced that, while the implementation of the SDGs relating to environment like climate change (Goal 13), life under the water (Goal 14) and life on land (Goal 15) are putting ever greater demands on the governments, business and civil society, all stakeholders need to cooperate and share the common goal of supporting and contributing to the implementation of the SDGs. They should be working together to produce and maintain public goods and engage in the necessary stakeholder interactions between all who share ownership of public goods. Building on interactions, like collective action, will become the foundation for social coherence and communal support, e.g., regarding the SDGs and other societal issues. A global focus on Agenda 2030 revives what has been postulated by Talcott Parsons more than eighty years ago in his social action theory (Parsons, 1949). Action/interaction needs to be linked to ethics in action - for the theme of this paper. It would mean sustainable progress for all is linked to concerted collective efforts by all stakeholders who partake in guaranteeing the future of mankind through a shared agency.

Funding. There is no funding for this research.

\section{References}

1. Ban, Ki-Moon (2015). In Ban calls on Global Compact to help end poverty, transform lives, protect planet. UN News, 9 January. Available at: https://news.un.org/en/story/2015/01/487952-ban-calls-globalcompact-help-end-poverty-transform-lives-protect-planet.

2. Bardy, R., Rubens, A., and Massaro, M. (2015). The systemic dimension of sustainable development in developing countries. Journal of Organisational Transformation \& Social Change, 12(1), 22-41. DOI:10.1179/1477963314Z.00000000033.

3. Beckmann, M., Hielscher, S., and Pies, I. (2014). Commitment strategies for sustainability: How business firms can transform trade-offs into win-win outcomes. Business Strategy and the Environment, 23(1), 18-37. DOI:10.1002/bse.1758.

4. Belal, A.R. (2017). Social and environmental accountability in developing countries. In M. Blowfield, C. Karam, and D. Jamali (Eds.), Development-Oriented Corporate Social Responsibility: Volume 1: Multinational Corporations and the Global Context. (pp. 153-166). New York: Routledge. Available at: https://www.researchgate.net/publication/281088455 Social and Environmental Accountability in Dev eloping Countries.

5. Bianchi, M. (2007). Reducing essential micronutrient malnutrition in developing countries: A BASF partnership. In Bianchi. M. (Eds.), Embedding Human Rights in Business Practice, Vol 2. (pp. 30-36). New York: United Nations Global Compact. Available at: https://www.ohchr.org/Documents/Publications/Embedding_II.pdf.

6. Bush G., Grayson, D., Jordan, A., and Nelson, J. (2008). Engaging Business in the Community: Not a quick fix. London: The Smith Institute. Available at: file:///C:/Users/lushi/Downloads/Engaging-business-in-thecommunity-not-a-quick-fix.pdf.

7. Calleja, R., and Melé, D. (2016). Political wisdom in management and corporate governance. Philosophy of Management, 15(2), 99-119. DOI:https://doi.org/10.1007/s40926-016-0037-7.

8. Carroll, A.B. (1991). The Pyramid of Corporate Social Responsibility: Toward the Moral Management of Organizational Stakeholders. Business Horizons, 34(4), 39-48. DOI:10.1016/0007-6813(91)90005-G.

9. Crane, A., Matten, D., Glozer, S., and Spence, L. (2019). Business ethics: Managing corporate citizenship and sustainability in the age of globalization. Oxford University Press, USA. Available at: http://infinity.wecabrio.com/198810075-business-ethics-managing-corporate-citizenship-and.pdf.

10.Doskočil, R., and Lacko, B. (2018). Risk management and knowledge - management as critical success factors of sustainability projects. Sustainability, 10(5), 1438-1450. DOI:10.3390/su10051438.

11.Frahm, K.A., and Martin, L.L. (2009). From Government to Governance: Implications for Social Work Administration. Administration in Social Work, 33(4), 407-422, DOI: 10.1080/03643100903173016.

12.Lafferty, W.M., and Eckerberg, K. (Ed.). (2013). From the Earth Summit to Local Agenda 21: working towards sustainable development. London: Routledge. https://doi.org/10.4324/9781315066585.

13.Mittler, D. (2001). Hijacking sustainability? Planners and the promise and failure of Local Agenda 21. In A. Layard, S. Davoudi and Batty (Eds.), Planning for a sustainable future (pp. 53-60). London:

Routledge. Available at:

https://books.google.com.ua/books?hl=ru\&lr=\&id=P51_ub0gXvQC\&oi=fnd\&pg=PA53\&ots=4wCRiBzN $\underline{\text { Uc\&sig=nMquR-afFOEWkwXr8jLCn23e3ww\&redir_esc=y\#v=onepage \&q\&f=false. }}$ 
14.Munro, D. J. (2008). Ethics in Action: Workable Guidelines for Private and Public Choices. Hong Kong: Chinese University Press. Available at: https://cup.columbia.edu/book/ethics-in-action/9789629963804.

15.Nugrahen, A.I.P, Priyambodo, T.K., Kusworo, H.A., Sutikno, B. (2019). The Social Dimension of Sustainable Development: Defining Tourism Social Sustainability, Tourism Studies Program, Graduate School of Universitas Gadjah Mada, Yogyakarta, Indonesia. Available at: https://eudl.eu/pdf/10.4108/eai.18-10-2019.2289855.

16.OECD (2006). Applying Strategic Environmental Assessment: Good Practice Guidance for Development Co-operation. DAC Guidelines and Reference Series, Paris: OECD. Available at: https://www.oecd.org/environment/environment-development/37353858.pdf.

17.Olson, M. (1971) [1965]. The Logic of Collective Action: Public Goods and the Theory of Groups (Revised ed.). Harvard University Press. Available at: https://en.wikipedia.org/wiki/The_Logic_of_Collective_Action/https://en.wikipedia.org/wiki/Collective_ action_problem.

18.Ostrom, E. (2012). The future of the commons: Beyond market failure and government regulation. London: Institute of Economic Affairs. Available at: https://www.researchgate.net/publication/256063870 The Future of the Commons Beyond Market F ailure_and_Government_Regulation.

19.Parsons, T. (1949). The structure of social action. New York: Free Press. Available at: https://www.icesi.edu.co/blogs/antro conocimiento/files/2012/02/Parsons Note-on-the-Concept-of-Fact.pdf.

20.Porter, M.E. and Kramer, M.R. (2011). Creating shared value. Harvard business review, 89, 62-77. Available at: https://hbr.org/2011/01/the-big-idea-creating-shared-value.

21.Sachs, J. D., Schmidt-Traub, G., Mazzucato, M., Messner, D., Nakicenovic, N., and Rockström, J. (2019). Six transformations to achieve the sustainable development goals. Nature Sustainability, 2(9), 805-814. DOI:10.1038/s41893-019-0352-9.

22.Saner, R. and Michalun, M. V. (eds.). (2009). Negotiations Between State Actors and Non-State Actors: Case Analyses From Different Parts Of The World. Dordrecht: Republic of Letters, B.V. Available at: https://www.semanticscholar.org/paper/Negotiations-between-state-actors-and-non-state-\%3A-SanerMichalun/64d634f7df7ac810574a626a61ebe098cff9358f.

23.Saner, R. and Yiu, L. (2014). Civil Society Organisations' Participation in the United Nations and Their Participation in the Aid Effectiveness Discourse and Related Standard-Setting Negotiations. Göymen, K., and Lewis, R. (eds.), Public Policymaking in a Globalised World. Istanbul: Istanbul Policy Centre at Sabanci University and Friedrich Naumann Stiftung. Available at: www.csend.org/images/articles/files/20150526_Participation_of_CSO_in_UN_in_Aid_Effectives.pdf.

24.Seitanidi, M.M., \& Crane, A. (2009). Implementing CSR through partnerships: Understanding the selection, design and institutionalisation of non-profit-business partnerships. Journal of Business Ethics, 85(2), 413-429. DOI:10.1007/s10551-008-9743-y.

25.Selman, P. (1998). Local Agenda 21: Substance or Spin? Journal of Environmental Planning and Management, 41(5), 533-553. DOI:10.1080/09640569811443.

26.UNESCAP (2009). What Is Good Governance? United Nations Economic and Social Commission for Asia and the Pacific, 1-3. Available at: https://www.unescap.org/sites/default/files/good-governance.pdf.

27.van Tulder, R., and van der Zwart, A. (2005). International Business-Society Management: Linking corporate responsibility and globalization. New York: Routledge. https://doi.org/10.1111/j.14679299.2007.00673_10.x.

28.Waddock, S.A. (1988). Building Successful Partnerships. Sloan Management Review, 29(4), 17-23. Available at: https://sloanreview.mit.edu/issue/summer-1988.

29.Yiu, L., and Saner, R. (2014). Sustainable Development Goals and Millennium Development Goals: an analysis of the shaping and negotiation process. Asia Pacific Journal of Public Administration, 36(2), 89-107. http://dx.doi.org/10.1080/23276665.2014.911487. 